\title{
Analisis Tingkat Kepuasan Konsumen Terhadap Produk Beras Organik PT Lingkar Organik Indonesia Di Kabupaten Sleman Daerah Istimewa Yogyakarta
}

\author{
Analysis of Consumer Satisfaction Level of Organic Rice Products PT. Lingkar \\ Organik Indonesia in Sleman District, Special Region of Yogyakarta
}
Salsabila Sifa Riyandani*, Ni Made Suyastiri Yani Permai, Indah Widowati
Program Studi Agribisnis, Jurusan Agribisnis, Fakultas Pertanian
Universitas Pembangunan Nasional "Veteran" Yogyakarta
J1. SWK No. 104, Kabupaten Sleman, Kabupaten Sleman, Daerah Istimewa
Yogyakarta Indonesia 55283
*email korespondensi : salsabilaa.ssr98@gmail.com

Diterima tanggal : 7 Desember 2021 ; Disetujui tanggal : 30 Desember 2021

\begin{abstract}
The importance of consumer satisfaction research on organic rice PT. Lingkar Organic Indonesia is to be able to determine the instability of organic rice sales, Lingkar Organic in Sleman Regency, Special Region of Yogyakarta. This study aims to (1) to analyze the effect of service quality, product quality, and price on consumer satisfaction in organic rice products of PT. Lingkar Organik Indonesia; (2) to analyze the level of customer satisfaction based on service quality, product quality, and organic rice product prices of PT. Lingkar Organik Indonesia. The method used in this research is descriptive analytical method. The research implementation is case study method. The method of sampling using purposive sampling. The data used in this study are primer and secondary data. Data collection of this study used interviews, questionnaires, and case studies. The analyzed methods used are Multiple Linear Regression and Importance Performance Analysis (IPA). Based on the results of the study, it can be concluded that: (1) Service quality, product quality, and price have an effect on consumer satisfaction with the organic rice product of PT. Lingkar Organik Indonesia, (2) The level of consumer in the unsatisfied category based on service quality, product quality, and price of organic rice products of PT. Lingkar Organik Indonesia.
\end{abstract}

Keywords : Consumer Satisfaction Level, Importance Performance Analysis, Organic Rice, Product Quality, Price, Service Qualit,.

\section{ABSTRAK}

Pentingnya penelitian kepuasan konsumen terhadap beras organik PT. Lingkar Organik Indonesia ini agar mampu mengetahui ketidak stabilan penjualan beras organik Lingkar Organik di Kabupaten Sleman, Daerah Istimewa Yogyakarta. Tujuan dari penelitian ini adalah : (1) Menganalisis pengaruh kualitas 
Riyandani et.al., Analisis Tingkat Kepuasan Konsumen Terhadap Produk Beras...

pelayanan, kualitas produk, dan harga terhadap kepuasan konsumen pada produk beras organik PT. Lingkar Organik Indonesia (2) Menganalisis tingkat kepuasan konsumen berdasarkan kualitas pelayanan, kualitas produk, dan harga produk beras organik PT. Lingkar Organik Indonesia. Metode yang digunakan dalam penelitian ini adalah metode deskriptif analitis. Pelaksanaan penelitian menggunakan metode studi kasus. Pengambilan sampel responden dilakukan dengan menggunakan metode purposive sampling. Data yang digunakan pada penelitian ini adalah data primer dan data sekunder. Pengumpulan data penelitian ini menggunakan wawancara, alat kuesioner, dan studi pustaka. Penelitian ini menggunakan teknik analisis Regresi Linier Berganda dan Importance Performance Analysis (Analisis Kinerja dan Kepentingan). Berdasarkan hasil penelitian dapat disimpulkan bahwa : (1) Kualitas pelayanan, kualitas produk, dan harga berpengaruh terhadap kepuasan konsumen pada produk beras organik PT. Lingkar Organik Indonesia (2)Tingkat kepuasan konsumen pada kategori belum puas berdasarkan kualitas pelayanan, kualitas produk, dan harga produk beras organik PT. Lingkar Organik Indonesia.

Kata Kunci : Analisis Kinerja dan Kepentingan, Beras Organik, Kepuasan Konsumen, Kualitas Pelayanan, Kualitas Produk.

\section{PENDAHULUAN}

Beras merupakan salah satu makanan pokok bagi sebagian besar masyarakat Indonesia. Menurut Putri (2018) Beras dipilih menjadi pangan pokok karena sumber daya alam lingkungan mendukung penyediaannya dalam jumlah yang cukup, mudah dan, cepat pengolahannya, memberi kenikmatan pada saat menyantap, dan aman dari segi kesehatan. Beras yang dikonsumsi tidaklah seharusnya terkontaminasi oleh zat-zat kimia. Beras organik merupakan hasil dari budidaya yang dilakukan dengan menggunakan pertanian organik. Mayrowani (2012) tujuan utama dari pertanian organik adalah untuk mengoptimalkan kesehatan dan produktivitas komunitas interdependen dari kehidupan di tanah, tumbuhan, hewan dan manusia. Sistem pertanian organik menggunakan bahanbahan organik tanpa zat kimia, seperti pupuk organik, kompos, pestisida organik maupun hayati. Sehingga beras organik memiliki gizi yang lebih tinggi dibandingkan dengan beras non organik. Menurut

PT. Lingkar Organik Indonesia merupakan salah satu produsen beras organik yang ada di Indonesia. Perusahaan ini bergerak pada pengolahan pertanian organik. Terdapat lebih dari 70 produk organik yang dipasarkan oleh PT. Lingkar Organik Indonesia. Salah satu produk andalan di perusahaan yaitu, 
produk beras organik. Ketersediaan produk-produk beras Lingkar Organik dapat dijumpai di beberapa agen atau reseller dan retailler yang tersebar di seluruh Indoensia. Hingga saat ini, jumlah agen dan retailler yang aktif mencapai lebih dari 1.000 orang, dan tersebar di seluruh Indonesia. Salah satunya yaitu di Provinsi Kabupaten Sleman, Daerah Istimewa Yogyakarta.

Walaupun sudah memiliki banyak reseller dan retailler, namun penjualan beras organik Lingkar Organik di Kabupaten Sleman, Daerah Istimewa Yogyakarta memiliki catatan penjualan yang tidak stabil pada tahun 2020. Hal ini dapat disebabkan oleh faktor kepuasan konsumen. Kepuasan konsumen terhadap suatu produk sangat dipengaruhi oleh kualitas produk, kualitas pelayanan, dan harga. Volume penjualan perusahaan sangat erat kaitannya dengan kepuasan konsumen, sehingga menjaga dan membuat konsumen puas akan produk beras organik merupakan hal yang penting untuk dilakukan perusahaan. Sebab, konsumen akan loyal kepada produk perusahaan, serta perusahaan akan memiliki citra yang semakin baik di kalangan masyarakat. Dan tentunya perusahaan mampu meningkatkan volume produksi dan penjualan mereka.

Adanya ketidak stabilan voulume penjualan beras organik PT. Lingkar Organik Indonesia tentu menjadi masalah penting bagi perusahaan. Untuk itu PT. Lingkar Organik Indonesia perlu mengetahui hal-hal yang mempengaruhi kepuasan konsumen melalui kualitas produk, kualitas pelayanan, dan harga. Berdasarkan latar belakang tersebut, penelitian ini bertujuan untuk menganalisis pengaruh kualitas pelayanan, kualitas produk, dan harga terhadap tingkat kepuasan konsumen pada produk beras organik PT. Lingkar Organik Indonesia di Kabupaten Sleman, Daerah Istimewa Yogyakarta serta bertujuan untuk menganalisis tingkat kepuasan konsumen berdasarkan kualitas pelayanan, kualitas produk, dan harga produk beras organik PT. Lingkar Organik Indonesia di Kabupaten Sleman, Daerah Istimewa Yogyakarta.

\section{METODE PENELITIAN}

Penelitian ini dilakukan di Loving Hut, Plaza Agro Mart, dan Peppermint Organics sebagai sampel penelitian pada produk beras organik 
Riyandani et.al., Analisis Tingkat Kepuasan Konsumen Terhadap Produk Beras...

Lingkar Organik. Pemilihan lokasi tersebut didasarkan pada sampel lokasi yang dianggap mampu mewakili konsumen beras organik Lingkar Organik di Kabupaten Sleman, Daerah Istimewa Yogyakarta. Metode yang digunakan dalam penelitian ini adalah metode deskriptif analitis. Menurut Hardyasar (2017) penelitian dilakukan menggunakan analisis data deskriptif yaitu untuk menggambarkan dan mengukur tingkat kepuasan konsumen beras organik Lingkar Organik. Pelaksanaan penelitian menggunakan metode studi kasus. Pengambilan sampel responden dilakukan dengan menggunakan metode purposive sampling. Menurut Notoatmodjo (2010), purposive sampling adalah pengambilan sampel yang berdasarkan atas pertimbangan tertentu seperti sifatsifat populasi ataupun ciri-ciri yang sudah diketahui sebelumnya. Kriteria responden yang digunakan yaitu konsumen yang melakukan pembelian beras organik Lingkar Organik yang dipasarkan di lokasi yang sudah ditentukan, sudah pernah melakukan 1 kali pembelian, dan berusia di atas 17 tahun. Data yang digunakan pada penelitian ini adalah data primer dan data sekunder. Pengumpulan data penelitian ini menggunakan wawancara, kuesioner, dan studi pustaka. Teknik analisis data yang digunakan pada penelitian ini yaitu Regresi Linier Berganda dan Importance Performance Analysis (Analisis Kinerja dan Kepentingan).

Teknik analisis Regresi Linier Berganda menurut Afnina dan Hastuti (2018) yaitu teknik analisis yang digunakan untuk mengetahui pengaruh beberapa variabel bebas terhadap variabel tidak bebas. Tujuan dari uji regresi linier berganda adalah untuk memprediksi nilai variabel tak bebas (Y) apabila nilai-nilai variabel bebasnya $(\mathrm{X} 1, \mathrm{X} 2 \ldots, \mathrm{Xn})$ diketahui. Disamping itu juga untuk dapat mengetahui bagaimanakah arah hubungan variabel tak bebas dengan variabel variabel bebasnya.

Persamaan regresi linier berganda secara matematik diekspresikan oleh :

$\mathrm{Y}=\mathrm{a}+\mathrm{b} 1 \mathrm{X} 1+\mathrm{b} 2 \mathrm{X} 2+\mathrm{b} 3 \mathrm{X} 3+\mathrm{e}$

Keterangan :

$\mathrm{Y} \quad=$ Kepuasan konsumen (skor)

a $\quad=$ konstanta (skor)

$\mathrm{b} 1, \mathrm{~b} 2, \mathrm{~b} 3=$ nilai koefisien regresi

$\mathrm{X} 1=$ kualitas pelayan an (skor)

$\mathrm{X} 2=$ kualitas produk (skor) 
X3 = harga (skor)

$\mathrm{E} \quad=$ Kesalahan pengganggu

Menurut Ong (2014) kepuasan pelanggan didefinisikan sebagai wujud perasaan konsumen setelah membandingkan dengan harapannya. Apabila kinerja perusahaan dibawah harapan konsumen maka konsumen akan kecewa dan sebaliknya sehingga dapat disimpulkan bahwa kepuasan merupakan respon dari pemenuhan kebutuhan konsumen.

Sedangkan Teknik Analisis Importance Performance Analysis menurut Supranto (2001) yaitu suatu metode untuk menganalisis sejauh mana tingkat kepuasan seseorang terhadap kinerja sebuah perusahaan. Menurut Kusmariza (2019) mtode Importance Performance Analysis menentukan apakah suatu atribut dianggap penting atau tidak oleh konsumen, dan apakah atribut tersebut memuaskan konsumen atau tidak. Berdasarkan hasil penilaian tingkat kepentingan/Importance dan hasil penelitian kinerja/Performance akan dihasilkan suatu penentuan mengenai tingkat kesesuaian antara tingkat kepentingan dan tingkat pelaksanaannya pada sebuah perusahaan.

\section{HASIL DAN PEMBAHASAN}

Penelitian ini dilakukan dengan menggunakan sampel 50 responden beras organik Lingkar Organik di Kabupaten Sleman, Daerah Istimewa Yogyakarta yang bertujuan untuk mengetahui pengaruh kualitas pelayanan, kualitas produk, dan harga terhadao kepuasan konsumen beras organik Lingkar Organik di Kabupaten Sleman, Daerah Istimewa Yogyakarta. Selain itu penelitian ini bertujuan untuk menganalisi tingkat kepuasan konsumen beras organik Lingkar Organik berdasarkan kualitas pelayanan, kualitas produk, dan harga di Kabupaten Sleman, Daerah Istimewa Yogyakarta.

\section{Pengaruh Kualitas Pelayanan, Kualitas Produk, dan Harga Terhadap} Kepuasan Konsumen Beras Organik PT. Lingkar Organik Indonesia

Hasil penelitian menunjukkan bahwa kualitas pelayanan, kualitas produk, dan harga berpengaruh secara individu ataupun berpengaruh secara bersama-sama terhadap kepuasan konsumen. Dalam hal ini, dapat diartikan bahwa kepuasan 
Riyandani et.al., Analisis Tingkat Kepuasan Konsumen Terhadap Produk Beras...

konsumen dapat didukung dengan kualitas pelayanan, kualitas produk, dan harga.

Tabel 1. Hasil Analisis Faktor-Faktor Yang Mempengaruhi Kepuasan Konsumen

\begin{tabular}{|c|c|c|c|c|c|}
\hline No & \multicolumn{2}{|c|}{ Variabel } & Koefisien & Thitung & Sig. \\
\hline 1. & \multicolumn{2}{|c|}{ Konstanta } & 1,295 & & \\
\hline 2. & \multicolumn{2}{|c|}{ Kualitas Pelayanan } & 0,602 & 2,414 & 0,020 \\
\hline 3. & \multicolumn{2}{|c|}{ Kualitas Produk } & 0,321 & 2,450 & 0,018 \\
\hline 4. & \multicolumn{2}{|c|}{ Harga } & 0,604 & 3,034 & 0,004 \\
\hline \multicolumn{3}{|c|}{ Adjusted $R$ Square $=0,543$} & & & \\
\hline \multicolumn{2}{|c|}{ Sig } & $=0,000$ & & & \\
\hline \multicolumn{2}{|c|}{ Fhitung } & $=20,391$ & & & \\
\hline \multicolumn{2}{|c|}{ Ftabel } & $=2,81$ & & & \\
\hline \multicolumn{2}{|c|}{ ttabel } & $=2,012$ & & & \\
\hline
\end{tabular}

Sumber : Data primer diolah, (2021)

Berdasarkan data tersebut didapatkan hasil output regresi linier berganda sesuai dengan data pada adjusted $R$ square yaitu 0,543. Yang berarti output regresi yang telah dipersentasekan yaitu 54,3\%. Dimana 54,3\% itu berarti variabel kualitas pelayanan, kualitas produk, dan harga mempengaruhi variabel kepuasan konsumen sebesar 54,3\%. Sedangkan 45,7\% dipengaruhi oleh faktor lain.

Sedangkan pada Uji F didapatkan hasil output regresi linier berganda bahwa $\mathrm{F}$ hitung sebesar 20,391. Sedangkan jika dilihat pada F tabel didapatkan sebesar 2,81. Hal ini menunjukkan bahwa $F$ tabel $<F$ hitung. Dan jika dilihat melalui signifikasi, didapatkan signifikasi sebesar 0,000 dengan alpha 0,05. Melalui ini dapat diketahui bahwa nilai signifikasi $<$ alpha. Sehingga dapat ditarik kesimpulan bahwa variabel kualitas pelayanan, kualitas produk dan variabel harga secara bersama-sama mempengaruhi kepuasan konsumen produk beras organik Lingkar Organik.

Berdasarkan uji t pada variabel kualitas pelayanan didapatkan hasil output kolom coefficient diketahui bahwa nilai t hitung sebesar 2,414 dan nilai signifikasi sebesar 0,020. Jika dibandingkan dengan $\mathrm{t}$ tabel sebesar 2,012 berarti nilai t hitung lebih besar dari t tabel. Sedangkan nilai signifikasi lebih kecil dari alpha yaitu $0,020<0,05$ yang berarti bahwa variabel kualitas pelayanan secara parsial atau individu berpengaruh terhadap kepuasan konsumen beras organik Lingkar Organik di Kabupaten Sleman, Daerah Istimewa Yogyakarta. 
Sedangkan uji t pada variabel kualitas produk didapatkan hasil output kolom coefficient diketahui bahwa nilai t hitung sebesar 2,450 dan nilai signifikasi sebesar 0,018. Jika dibandingkan dengan t tabel sebesar 2,012 berarti nilai t hitung lebih besar dari t tabel. Sedangkan nilai signifikasi lebih kecil dari alpha yaitu $0,018<0,05$ yang berarti variabel kualitas produk secara parsial atau individu berpengaruh terhadap kepuasan konsumen beras organik Lingkar Organik di Kabupaten Sleman, Daerah Istimewa Yogyakarta.

Serta uji t pada variabel harga didapatkan hasil output kolom coefficient diketahui bahwa nilai t hitung sebesar 3,034 dan nilai signifikasi sebesar 0,004. Jika dibandingkan dengan $\mathrm{t}$ tabel sebesar 2,012 berarti nilai $\mathrm{t}$ hitung lebih besar dari t tabel. Sedangkan nilai signifikasi lebih kecil dari alpha yaitu 0,004<0,05 yang berarti bahwa variabel harga secara parsial atau individu berpengaruh terhadap kepuasan konsumen beras organik Lingkar Organik di Kabupaten Sleman, Daerah Istimewa Yogyakarta.

Berdasarkan hasil output didapatkan nilai konstanta 1,295 sedangkan koefisien kualitas pelayanan 0,602 kualitas produk memiliki nilai koefisien 0,321 dan nilai koefisien promosi sebesar 0,604. Dengan demikian persamaan regresinya adalah sebagai berikut:

$$
\mathrm{Y}=1,295+0,602 \mathrm{X} 1+0,321 \mathrm{X} 2+0,604 \mathrm{X} 3+\mathrm{e}
$$

Hasil persamaan di atas dapat diartikan nilai koefisien regresi variabel kualitas pelayanan bernilai positif sehingga dapat diketahui bahwa semakin meningkatkan kualitas pelayanan maka kepuasan konsumen semakin meningkat. Selain itu dapat diketahui nilai koefisien variabel kualitas produk bernilai positif sehingga dapat diketahui bahwa semakin meningkatkan kualitas produk maka kepuasan konsumen semakin meningkat. Dan nilai koefisien variabel harga bernilai positif sehingga dapat diketahui bahwa semakin meningkatkan harga maka kepuasan konsumen semakin meningkat.

\section{Analisis Tingkat Kepuasan Konsumen Beras Organik PT. Lingkar Organik Indonesia di Kabupaten Sleman, Daerah Istimewa Yogyakarta}

Berdasarkan hasil penelitian, diidapatkan data pada lapangan bahwa 
Riyandani et.al., Analisis Tingkat Kepuasan Konsumen Terhadap Produk Beras...

penilaian konsumen terhadap tingkat kepentingan dan kinerja memiliki skor pada kategori tinggi. Namun, jika dibandingkan skor kepentingan lebih tinggi dibandingkan dengan penilaian konsumen pada tingkat kinerja perusahaan. Hal ini melihatkan bahwa kinerja yang diberikan oleh perusahaan lebih kecil atau kurang dibandingkan dengan kepentingan yang diinginkan konsumen.

Selain itu, didapatkan penilaian konsumen pada kinerja perusahaan lebih rendah dibandingan penilaian pada kepentingan konsumen. Hal ini menyebabkan tingkat kesesuaian di bawah $100 \%$ atau diartikan konsumen belum puas. Gap yang besar menandakan bahwa konsumen belum merasakan kepuasan terhadap pelayanan yang didapatkan. Hal ini dapat dilihat pada tabel 2.

Tabel 2. Perhitungan Rata-Rata Nilai Kepentingan dan Kinerja Kepuasan Konsumen Berdasarkan Variabel Kualitas Pelayanan, Kualitas Produk, dan Harga.

\begin{tabular}{|c|c|c|c|c|c|}
\hline \multirow[t]{2}{*}{ No } & \multirow[t]{2}{*}{ Indikator Pertanyaan } & \multicolumn{2}{|c|}{ Jumlah } & \multicolumn{2}{|c|}{ Rata-Rata } \\
\hline & & $\mathbf{X}$ & $\mathbf{Y}$ & $\overline{\bar{X}}$ & $\bar{Y}$ \\
\hline \multicolumn{6}{|c|}{ Variabel Kualitas Pelayanan } \\
\hline 1. & 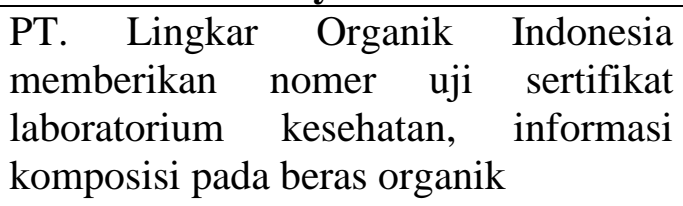 & 200 & 225 & 4 & 4,50 \\
\hline 2. & $\begin{array}{l}\text { Memberikan pelayanan yang cepat dan } \\
\text { tanggap ketika stock suatu produk } \\
\text { kosong }\end{array}$ & 179 & 223 & 3,58 & 4,46 \\
\hline \multicolumn{6}{|c|}{ Variabel Kualitas Produk } \\
\hline 3. & $\begin{array}{l}\text { Kemasan yang digunakan sudah aman } \\
\text { sesuai keinginan konsumen }\end{array}$ & 208 & 229 & 4,16 & 4,58 \\
\hline 4. & $\begin{array}{l}\text { Memiliki rasa yang sesuai dengan } \\
\text { keinginan konsumen }\end{array}$ & 215 & 226 & 4,30 & 4,52 \\
\hline 5. & $\begin{array}{l}\text { Beras organik Lingkar Organik } \\
\text { memiliki variasi produk. }\end{array}$ & 204 & 213 & 4,08 & 4,26 \\
\hline 6. & $\begin{array}{l}\text { Beras organik Lingkar Organik } \\
\text { memiliki daya tahan yang baik jika } \\
\text { disimpan dalam waktu yang cukup } \\
\text { lama }\end{array}$ & 197 & 225 & 3,94 & 4,50 \\
\hline 7. & $\begin{array}{lrr}\text { Beras organik } & \text { Lingkar } & \text { Organik } \\
\text { memberikan } & \text { informasi } & \text { hari } \\
\text { kadaluwarsa } & & \end{array}$ & 214 & 228 & 4,28 & 4,56 \\
\hline 8. & $\begin{array}{l}\text { Kemasan Beras Organik Lingkar } \\
\text { Organik memiliki desain yang menarik }\end{array}$ & 193 & 197 & 3,86 & 3,94 \\
\hline
\end{tabular}


Jurnal Dinamika Sosial Ekonomi, 22 (2) : 126-140

\begin{tabular}{|c|c|c|c|c|c|}
\hline \multirow[t]{2}{*}{ No } & \multirow[t]{2}{*}{ Indikator Pertanyaan } & \multicolumn{2}{|c|}{ Jumlah } & \multicolumn{2}{|c|}{ Rata-rata } \\
\hline & & $\mathbf{X}$ & $\mathbf{Y}$ & $\bar{X}$ & $\bar{Y}$ \\
\hline \multicolumn{6}{|c|}{ Variabel Harga } \\
\hline 9. & $\begin{array}{lrr}\text { Kesesuaian } & \text { harga } & \text { dengan } \\
\text { kualitas } & \text { beras } & \text { organik } \\
\text { Lingkar } & \text { Organik } & \text { di } \\
\text { Kabupaten } & \text { Sleman, Daerah } \\
\text { Istimewa Yogyakarta } & \end{array}$ & 197 & 224 & 3,94 & 4,48 \\
\hline 10. & $\begin{array}{l}\text { Harga beras organik Lingkar } \\
\text { Organik di Kabupaten } \\
\text { Sleman, Daerah Istimewa } \\
\text { Yogyakarta mampu bersaing } \\
\text { dengan produk beras organik } \\
\text { lain }\end{array}$ & 167 & 197 & 3,34 & 3,94 \\
\hline 11. & $\begin{array}{l}\text { Harga beras organik Lingkar } \\
\text { Organik di Kabupaten } \\
\text { Sleman, Daerah Istimewa } \\
\text { Yogyakarta terjangkau oleh } \\
\text { konsumen }\end{array}$ & 194 & 210 & 3,88 & 4,20 \\
\hline & JUMLAH & 2168 & 2397 & 43,36 & 47,94 \\
\hline
\end{tabular}

\begin{tabular}{l}
\hline Sumber $\quad$ : Data primer diolah, (2021) \\
Keterangan : \\
$\begin{array}{ll}\mathrm{X} \quad \text { = Jumlah Tingkat Kinerja } \\
\overline{\mathrm{Y}} \quad=\text { Jumlah Tingkat Kepentingan } \\
\overline{\mathrm{X}} \quad=\text { Rata-Rata Tingkat Kinerja } \\
\overline{\mathrm{Y}} \quad=\text { Rata-Rata Tingkat Kepentingan }\end{array}$
\end{tabular}

Kriteria :

Sangat puas : tingkat kesesuaian $>100 \%$ atau mean kinerja $>$ mean kepentingan Puas $\quad$ : tingkat kesesuaian $=100 \%$ atau mean kinerja $=$ mean kepentingan Belum puas : tingkat kesesuaian $<100 \%$ atau mean kinerja $<$ mean kepentingan

Total Tingkat Kesesuaian :

$$
\begin{aligned}
\text { TKi total } & =\frac{\sum X i}{\sum \sum^{Y} i} \times 100 \% \\
& =\frac{2168}{2397} \times 100 \% \\
& =90,44 \%
\end{aligned}
$$

Berdasarkan tabel 2 didapatkan tingkat kesesuaian total sebesar 90,44\% dengan nilai rata-rata tingkat kinerja lebih kecil dibandingkan nilai rata-rata tingkat kepentingan. Dengan hal ini dapat disimpulkan bahwa secara keseluruhan pada variabel kualitas pelayanan, kualitas produk, dan harga konsumen belum merasa puas berdasarkan tingkat kesesuaian antara importance (kepentingan) dan 
Riyandani et.al., Analisis Tingkat Kepuasan Konsumen Terhadap Produk Beras...

performance (kinerja) pada produk beras organik Lingkar Organik. Tidak puasnya konsumen menunjukkan bahwa kualitas pelayanan, kualitas produk, dan harga yang diberikan oleh PT. Lingkar Organik Indonesia selaku produsen beras organik Lingkar Organik belum sesuai dengan keinginan atau harapan konsumen.

Diagram Cartesius Importance Performance Analysis merupakan diagram yang dibagi menjadi empat bagian yang dibatasi oleh dua garis yang berpotongan tegak lurus pada titik-titik (X dan Y). Nilai X yakni sumbu yang mencerminkan kinerja (X) atau persepsi pelanggan. Sedangkan nilai Y yakni sumbu yang mencerminkan kepentingan atau harapan pelanggan. Setelah dilakukan olah data, indikator pertanyaan yang diteliti tersebar ke empat kuadran pada Diagram Cartesius. Hal ini dapat dilihat pada Gambar 1.

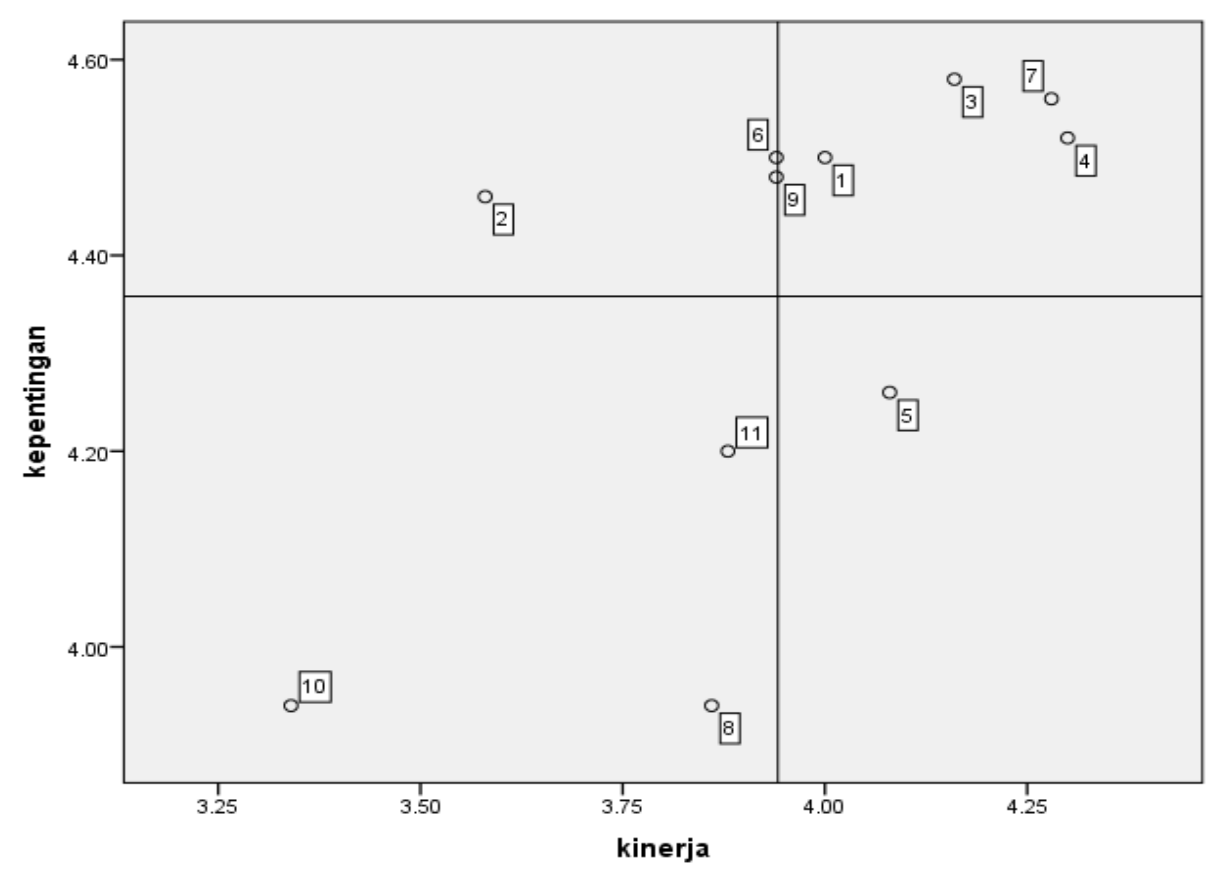

Gambar 1. Diagram Cartesius Importance Performance Analysis Kualitas Produk, Kualitas Pelayanan, dan Harga Produk Beras Organik Lingkar Organik

Sumber : Data primer diolah (2021)

Keterangan :

1. PT. Lingkar Organik Indonesia memberikan nomer uji sertifikat laboratorium kesehatan, informasi komposisi pada beras organik.

2. Memberikan pelayanan yang cepat dan tanggap ketika stock suatu produk kosong.

3. Kemasan yang digunakan sudah aman sesuai keinginan konsumen.

4. Memiliki rasa yang sesuai dengan keinginan konsumen. 
Jurnal Dinamika Sosial Ekonomi, 22 (2) : 126-140

5. Beras organik Lingkar Organik memiliki variasi produk.

6. Beras organik Lingkar Organik memiliki daya tahan yang baik jika disimpan dalam waktu yang cukup lama

7. Beras organik Lingkar Organik memberikan informasi hari kadaluwarsa.

8. Kemasan Beras Organik Lingkar Organik memiliki desain yang menarik.

9. Kesesuaian harga dengan kualitas beras organik Lingkar Organik di Kabupaten Sleman, Daerah Istimewa Yogyakarta.

10. Harga beras organik Lingkar Organik di Kabupaten Sleman, Daerah Istimewa Yogyakarta mampu bersaing dengan produk beras organik lain.

11. Harga beras organik Lingkar Organik di Kabupaten Sleman, Daerah Istimewa Yogyakarta terjangkau oleh konsumen

Berdasarkan analisis Importance Performance Analysis didapatkan indikator pertanyaan yang termasuk pada kuadran A, kuadran B, kuadran C dan kuadran D. Setiap kuadran memiliki arti yang berbeda-beda. Kuadran A biasa disebut sebagai prioritas utama, atau menunjukkan faktor-faktor yang dianggap penting oleh konsumen dalam memenuhi kepuasan konsumen, namun dalam kinerjanya PT. Lingkar Organik Indonesia belum mampu memenuhi. Kuadran B menunjukkan faktor-faktor yang dianggap penting oleh konsumen dalam memnuhi kepuasan konsumen dan dalam kinerjanya perusahaan telah mampu memenuhinya. Kuadran C menunjukkan faktor-faktor yang dianggap tidak terlalu mempengaruhi kepuasan konsumen oleh konsumen dan dalam kinerjanya perusahaan menanggapi secara netral. Sedangkan kuadran D menunjukkan faktorfaktor yang dianggap konsumen tidak terlalu mempengaruhi kepuasan konsumen, dan dalam kinerjanya perusahaan telah memberikan secara berlebih.

Menurut Indrajaya (2018) indikator pertanyaan yang berada dalam kuadran A harus lebih diprioritaskan dan diperbaiki, sehingga kinerjanya meningkat dan menjadi lebih baik lagi, karena atribut-atribut ini memiliki nilai kepentingan yang tinggi bagi konsumen, namun kinerjanya masih kurang memuaskan. Kuadran A ini sangat penting diperhatikan oleh perusahaan, sebab di kuadran ini perusahaan mampu memprioritaskan masalah yang ada dan mampu untuk memperbaiki atau meningkatkan sesuai dengan harapan konsumen. Jika pada kuadran A ini tidak dilakukan perbaikan, dapat menyebabkan konsumen merasa tidak puas dan menjadi tidak loyal pada perusahaan bahkan dapat menyebabkan konsumen berpindah menjadi konsumen di perusahaan pesaing. 
Riyandani et.al., Analisis Tingkat Kepuasan Konsumen Terhadap Produk Beras...

Indikator pertanyaan yang masuk pada kuadran A yaitu, pemberian pelayanan yang cepat tanggap terhadap stock kosong, daya tahan penyimpanan beras organik, dan kesesuaian antara kualitas produk dengan harga. Solusi yang bisa dilakukan oleh perusahaan dengan menambah jumlah sumber daya manusia pada bagian pengadaan barang dan menambah jalinan kerjasama dengan petani beras organik, sehingga perusahaan mampu memenuhi permintaan beras organik Lingkar Organik dan mampu mengindari kekosongan stock. Selain itu perusahaan disarankan untuk menggunakan kemasan vakum pada produk beras organik Lingkar Organik. Hal ini mampu meningkatkan masa simpan produk 3-5x lebih awet dibandingkan dengan kemasan tanpa vakum. Hal lain yang bisa dilakukan dengan menyesuaikan kualitas produk yang ditawarkan dengan harga, seperti dengan menambahkan kandungan gizi beras organik Lingkar Organik yang belum ada.

Menurut Indrajaya (2018) indikator pertanyaan yang termasuk ke dalam kuadran B merupakan atribut-atribut yang dianggap penting oleh pelanggan dan kinerja dari pihak perusahaan pada atribut ini juga sudah sangat baik, sehinggan pelanggan merasa puas. Pada kuadran B atau biasa disebut pertahankan prestasi. Harapannya perusahaan memeprtahankan atau meningkatkan indikator-indikator yang berada di kuadran ini akan mampu meningkatkan kepuasan konsumen dan mampu membuat konusmen merasa loyal terhadap produk beras organik Lingkar Organik. Indikator pertanyaan pada kuadran B yaitu, pemberian uji sertifikat kesehatan dan komposisi, kemasan yang aman, cita rasa yang sesuai, dan pemberian hari kadaluwarsa.

Menurut Indrajaya (2018) indikator pertanyaan yang termasuk ke dalam kuadran $\mathrm{C}$ merupakan atribut-atribut yang dianggap kurang penting oleh pelanggan dan kinerjanya pada atribut ini juga kurang begitu diperhatikan karena atribut-atribut pada kuadran tiga merupakan atributatribut yang kurang berpengaruh terhadap kepuasan konsumen. Pada kuadran $\mathrm{C}$ biasa disebut sebagai prioritas rendah. Kuadran $\mathrm{C}$ tidak dianggap penting oleh konsumen, sehingga jika produsen meningkatkan kinerjanya tidak akan memberikan kepuasan konsumen secara signifikan. Indikator pertanyaan 
Jurnal Dinamika Sosial Ekonomi, 22 (2) : 126-140

pada kuadran C yaitu, desain kemasan, kemampuan bersaing harga, keterjangkauan harga.

Pada kuadran D biasa disebut sebagai berlebihan. Menurut Drajat (2018) kuadran D menunjukkan indikator pertanyaan yang dirasa kurang penting oleh pelanggan, tetapi kinerjanya dilakukan dengan baik sehingga pelanggan menilai kinerja tersebut dirasakan berlebihan. Sehingga dalam pelaksanaannya kurang efektif untuk memberikan kepuasan terhadap konsumen. Indikator pertanyaan yang masuk pada kuadran D yaitu, variasi produk. Hal ini disebabkan beras Lingkar Organik memiliki 9 varietas beras yang ditawarkan. Selain itu dalam pilihannya, setiap beras dibedakan menjadi kemasan $1 \mathrm{~kg}, 2,5 \mathrm{~kg}$, dan $5 \mathrm{~kg}$. Konsumen menganggap pilihan variasi yang ditawarkan oleh perusahaan terlalu banyak baik dari segi rasa maupun berat kemasan sedangkan dengan banyaknya variasi tidak dianggap terlalu penting oleh konsumen dalam memenuhi kepuasannya. Namun, kinerja yang diberikan oleh perusahaan sudah berlebih, sehingga dalam pelaksanaannya tidak akan memberikan dampak yang signifikan terhadap kepuasan konsumen.

\section{SIMPULAN}

Kualitas pelayanan, kualitas produk, dan harga berpengaruh terhadap kepuasan konsumen pada produk beras organik PT. Lingkar Organik Indonesia di Kabupaten Sleman, Daerah Istimewa Yogyakarta. Tingkat kepuasan konsumen dikatakan belum puas berdasarkan kualitas pelayanan, kualitas produk, dan harga produk beras organik PT. Lingkar Organik Indonesia di Kabupaten Sleman, Daerah Istimewa Yogyakarta.

Peneliti menyarankan kepada PT. Lingkar Organik Indonesia untuk memperbaiki yaitu meningkatkan kinerja perusahaan terutama pada indikator pertanyaan yang termasuk di Kuadran A (Priorotas Utama) yakni dilakukan dengan memperbaiki kualitas pelayanan terhadap stock beras organik Lingkar Organik yang kosong. Permasalahan tidak tanggapnya perusahaan terhadap stock beras organik Lingkar Organik disebabkan karena sumber daya manusia perusahaan kurang memadahi dibandingkan dengan permintaan yang masuk. 
Riyandani et.al., Analisis Tingkat Kepuasan Konsumen Terhadap Produk Beras...

Untuk mengatasi hal ini dapat dilakukan dengan cara menambah sumber daya manusia pada bagian pengadaan barang ataupun menambah jalinan kerjasama dengan petani beras organik dalam hal produksi. Sehingga perusahaan mampu menampung semua permintaan beras organik sesuai dengan kapasitas perusahaan dan menghindari kekosongan stock yang dapat menyebabkan konsumen menunggu terlalu lama, bahkan dapat menyebabkan konsumen berpindah ke pesaing beras organik Lingkar Organik.

Selain itu dalam hal memiliki daya tahan yang lama pada produk beras organik Lingkar Organik dapat dilakukan dengan cara memberikan kemasan vakum pada produk beras organik Lingkar Organik yang dipasarkan di Kabupaten Sleman, Daerah Istimewa Yogyakarta. Sebab dengan menggunakan kemasan vakum akan menjaga kesegaran produk $3-5 x$ lebih awet atau tahan lama dibandingkan dengan kemasan tanpa vakum. Pengemasan vakum menggunakan sistem pengemasan hampa udara sehingga mampu memperpanjang umur simpan.

Sedangkan pada hal kesesuaian harga dengan kualitas dapat dilakukan dengan menetapkan harga sesuai dengan kualitas produk yang ditawarkan atau harga yang ditetapkan tidak melebihi dari harga pesaing yang menawarkan kualitas sama misalnya dapat dilakukan salah satunya dengan melengkapi informasi kandungan gizi atau dapat melakukan branding dengan menjelaskan perbedaan produk beras organik Lingkar Organik dengan produk pesaing, sehingga dengan ditetapkannya harga tersebut dapat dinilai sesuai oleh konsumen. Memperhatikan tingkat kepentingan konsumen, karena tingkat kepentingan sudah termasuk pada kategori tinggi dengan cara menerima saran terhadap kebutuhan dan keinginan konsumen.

\section{DAFTAR PUSTAKA}

Afnina dan Yulia Hastuti. (2018). Pengaruh Kualitas Produk Terhdap Kepuasan Pelanggan. Jurnal Samudra Ekonomi dan Bisnis, 9, (1), 21-30.

Engel, James, Roger Blackwell, Paul Miniard. (1994). Perilaku Konsumen Jilid 1. Jakarta : Binarupa Aksara.

Hardyasar, Arthur. (2017). Tingkat Kepuasan Konsumen Restoran Pondok Hijau 
Jurnal Dinamika Sosial Ekonomi, 22 (2) : 126-140

Kota Manado. Jurnal Agri-Sosio Ekonomi Unsrat.,13, (3): 157-172.

Indrajaya, Drajat. (2018). Analisis Kualitas Pelayanan Terhadap Tingkat Kepuasan Konsumen Menggunakan Metode Importance Performance Analysis dan Customer Statisfaction Index Pada UMKM Gallery. Jurnal IKRA-ITH Teknologi. (2) (3), 1-6.

Kusmariza, Nella. (2019). Analisis Kepuasan Konsumen Terhadap Beras di Desa Pasar Baru Pangean Kecamatan Pangean Kabupaten Kuantan Singingi Provinsi Riau. Jurnal Agribusiness Future, 1 (1), 22-38.

Mayrowani, Henny. (2012). Pengembangan Pertanian Organik di Indonesia. Jurnal Forum Penelitia Agro Ekonomi, 30 (2), 91-108.

Notoatmodjo, S. (2010). Metodologi Penelitian Kesehatan. Jakarta : Rineka Cipta.

Ong, Johan Oscar. (2014). Analisis Kepuasan Pelanggan dengan Importance Performance Analysis di SBU Laboratory Cibitung PT Sucofindo (Persero). Jurnal Jati Undip, 9( 1), 1-10.

Putri, Asgami. (2018). Tingkat Kepuasan Konsumen terhadap Mutu Beras di Kampung Bunga Raya Kabupaten Siak. Jurnal of Agribusiness and Community Empowerment., 2, (1), 1-9.

Supranto, J. (2011). Pengukuran Tingkat Kepuasan Pelanggan. Jakarta: Rineka Cipta. 